\title{
Proposed Wastewater Treatment Plant for a Paper Mill
}

\author{
Arshad Ali and Muhammad Jawed Iqbal
}

\begin{abstract}
The decline in the availability and alarming pollution of the existing water resources is the major environmental problem of third-world countries. The main reason of water pollution is the disposal of untreated industrial effluents. This study was designed to evaluate the pollution load caused by a paper mill, and to propose a wastewater treatment plant design, based on the analyses of wastewater samples. The wastewater samples were collected from the local paper mill for a period of more than four months on a regular basis. The $\mathrm{pH}$, temperature, color, TSS, TDS, BOD, COD and $\mathrm{AOX}$ were measured as, 8.1, 23ㅇ $\mathrm{C}, 2,431 \mathrm{PtCo}$ unit, $956 \mathrm{mg} / \mathrm{L}, 3,046 \mathrm{mg} / \mathrm{L}, 1,582 \mathrm{mg} / \mathrm{L}, 2,492 \mathrm{mg} / \mathrm{L}$ and 19.81 $\mathrm{mg} / \mathrm{L}$, respectively. Based on the data obtained, the wastewater treatment plant consisting of a screening chamber, primary sedimentation tank and a UASB reactor was designed. It was concluded that the treatment efficiency of more than $75 \%$ removal of BOD and COD concentrations could be accomplished. The treatment plant will also be able to produce $2,200 \mathrm{~m}^{3} /$ day of biogas.
\end{abstract}

Key words: Water pollution, paper mill, treatment plant, biogas

\section{Introduction}

W ater pollution is a major problem in the global context. In order to save the environment from the undesirable impacts of untreated industrial effluents, it is obligatory that all the industrial wastewater be treated prior to releasing them to the receiving streams or rivers. Most of the prevailing waterborne diseases are due to freshwater being contaminated with pathogenic microbes. It has been observed that water pollution causes thousands of deaths per day in the world. Pakistan is gifted with plenty of water resources, both surface water and groundwater. The major adverse impacts on the decline and shortage of the prevailing water resources is the rapid and exponential population growth, urbanization and industrial expansion; which have multiple loads on the water reservoir of the nation (Jehangir 2002; Imran et al 2009). The comprehensive famine and non-development of supplementary water resources have additionally provoked the water shortage condition. As a result, per capita water accessibility has declined from $5,600 \mathrm{~m}^{3}$ to $1,000 \mathrm{~m}^{3}$ per annum from 1960 to 2010 . The escalating gap between the demand of water and its supply is quite serious and has further led to harsh water shortages in almost all sectors. The supply and demand of water and its rising struggle for various applications of water has badly affected the excellence of water quality. Different researches and studies by numerous organizations have suggested that the quality of water, in terms of its pollution has turned out to be a severe dilemma in Pakistan. The majority of the problems associated with human health are, in one way or the other, associated with the pollution of water. The overall concerns of water pollution invite for the immediate preparation of proficient development, utilization and monitoring of the water resources of the country (Khurrum 2010; Tallat et al 2011). On one side, the accessibility of fresh water is being dilapidated day by day and, on the other hand, the fresh water obtainable is being polluted at a shocking rate owing to the discharge of untreated domestic and industrial effluents and agricultural runoff. In Pakistan there is no such appropriate waste administration system for industrial effluents; consequently, it is very important to appraise and work out probable improvement measures for waste management and secure disposal using potential cost effective methods (Pak-EPA Draft 1999).

A wide range of physical, chemical, electrochemical and biological procedures have been tried to reduce the concentrations of the effluents from the paper industries. The physical and chemical procedures offer guaranteed results in terms of pollution decrease in the wastes, but they are exceptionally costly in terms of their operational and maintenance costs, and therefore, biological treatment procedures are usually selected. Because the pollution disasters in the third world nations are relatively severe and as these nations cannot retain waste handling schemes by means of high operational costs. Hence, reasonably economical and easy technologies should be established for its appropriate management. Aerobic processes incur massive consumption of energy, making it costly for the third world nations. Using the anaerobic process that is easy, practically economical and uses extremely minimum energy is deemed to be one of the most hopeful preferences for pollution reduction caused by different kinds of wastes, along with the pulp and paper industrial waste (Bhatti 1996; Arshad and Hashim 2010). In addition, the aerobic process is not much capable in reducing the pulping effluent pollution to a large extent; as a result, a lot of consideration is being given to anaerobic digestion. The anaerobic digestion is a cheaper process in the elimination of a variety of pollutants, and is broadly recognized too for reducing the environmental impacts of various wastes, including domestic and industrial wastewater. There is an increase in awareness in the operation of numerous anaerobic components throughout the globe, including the treatment of wastewaters from paper industries (Schellinkhout 1993; Arshad et al 2009).

This study was conducted to investigate the wastewater characteristics of a local paper mill and 
to design an anaerobic treatment unit to estimate the amount of biogas produced during the process.

\section{Materials and Methodology}

The wastewater samples were collected from the local paper mill. The main wastewater characteristics of the effluent like $\mathrm{pH}$, temperature, TDS (Total Dissolved Solids), TSS (Total Suspended Solids), DO (Dissolved Oxygen), COD (Chemical Oxygen Demand), BOD (Biochemical Oxygen Demand), AOX (Absorbable Organic Halides) etc. were analyzed using standard methods (AWWA 2005), as mentioned in the Table 1.

\begin{tabular}{|l|l|}
\hline \multicolumn{1}{|c|}{ pH } & \multicolumn{1}{c|}{ HACH pH meter } \\
\hline Temperature & Portable digital thermometer \\
\hline Color & HACH colorimeter \\
\hline TDS/TSS & Gravimetric technique \\
\hline DO & HACH digital DO meter \\
\hline BOD & Dilution method \\
\hline COD & Open reflux \\
\hline AOX & DR/2010 Spectrophotometer \\
\hline
\end{tabular}

Table 1. Analysis Technique used in this Study.

\section{Results and Discussion \\ Wastewater Characteristics of the Paper Mill}

The wastewater characteristics of the local paper mill are shown in the Table 2. The results indicate that the effluent of the mill is slightly alkaline, having a $\mathrm{pH}$ of more than 8.o. Due to excessive usage of the chlorinated compounds during the bleaching process, the final effluent is highly colored, the value being 2,431 units as observed. Owing to enormous raw material fibers in the wastewater streams, the TSS observed was $956 \mathrm{mg} / \mathrm{L}$. Such a high concentration of TSS results in decreasing the photosynthetic activities of the aquatic flora, by decreasing the light penetration and ultimately creating anaerobic conditions within the receiving streams, thus leading towards ultimate bedlam. The inorganic and dissolved solids contribute to the unaesthetic condition of the wastes streams. The color of the effluent is due to the presence of excessive dissolved solids. The concentration of TDS was very high, i.e. $3,046 \mathrm{mg} / \mathrm{L}$. Similarly, the concentration of BOD and COD were observed as $1,582 \mathrm{mg} / \mathrm{L}$ and 2,492 $\mathrm{mg} / \mathrm{L}$, respectively. These two parameters define the polluting strength of the sewage; the more the BOD and COD, the more will be the extent of pollution due to that particular waste. The National Environmental Quality Standards (NEQS) of Pak-EPA permits the disposal of effluent with maximum of $80 \mathrm{mg} / \mathrm{L}$ and $150 \mathrm{mg} / \mathrm{L}$ of BOD and COD, respectively. Though the NEQS are set only for 32 parameters, and the concentration and limitation of the AOX are not yet defined, in this study the AOX concentration was found to be $19.81 \mathrm{mg} / \mathrm{L}$ (Pak-EPA Draft 1999). The AOX is formed in the effluent of paper industries, due to the chemical interaction of residual lignin and chlorinated effluent from the bleaching process. Most of the compounds of the AOX are carcinogenic, bio-accumulative and persistent (Savant 2005).

\begin{tabular}{|l|c|}
\hline \multicolumn{1}{|c|}{$\mathbf{p H}$} & $\mathbf{8 . 1}$ \\
\hline Temperature, OC & 23 \\
\hline Color, PtCo unit & 2431 \\
\hline TDS, $\mathrm{mg} / \mathrm{L}$ & 3046 \\
\hline TSS, $\mathrm{mg} / \mathrm{L}$ & 956 \\
\hline DO, mg/L & 5.3 \\
\hline BOD, $\mathrm{mg} / \mathrm{L}$ & 1582 \\
\hline COD, $\mathrm{mg} / \mathrm{L}$ & 2492 \\
\hline AOX, mg/L & 19.81 \\
\hline
\end{tabular}

Table 2. Wastewater Characteristics of the Paper Mill.

\section{Proposed Wastewater Treatment Plants}

Based on the results of wastewater characteristics of the paper mill effluent, a wastewater treatment plant was designed as a proposed solution in order to reduce the load of pollution and to contribute to the energy sector too. Table 3 shows the various design assumptions and specification being practiced during the design process of the study. The layout of the proposed wastewater treatment plant is shown in the Figure 1.

\begin{tabular}{|l|}
\hline Paper production $=1$ ton \\
\hline Total head $=2 \mathrm{~m}$ (for pumping) \\
\hline Treatment units \\
\hline Screening, PST, UASB reactor \\
\hline Design criteria for primary sedimentation tank, PST \\
\hline SOR $=2.81 \mathrm{ft} 3 / \mathrm{ft} 2-\mathrm{hr}$ \\
\hline HDT $=2 \mathrm{hrs}$ \\
\hline Design criteria for UASB reactor \\
\hline Depth $=12 \mathrm{ft}$ \\
\hline Up-flow velocity $=1.5 \mathrm{ft} / \mathrm{hr}$ \\
\hline HDT $=8 \mathrm{hrs}$ \\
\hline VLR $=3.5 \mathrm{~kg}-\mathrm{COD} / \mathrm{m}^{3}$-day \\
\hline$\%$ COD removal $=80 \%$ \\
\hline$\%$ BOD removal $=70 \%$ \\
\hline
\end{tabular}

Table 3. Design Assumptions/Specifications.

The wastewater characteristics and data employed in the design have been extracted from the results obtained during the laboratory analysis of this study, i.e.,

Flow rate, $\mathrm{Q}=0.05 \mathrm{~m}^{3} / \mathrm{sec}$

$\mathrm{pH}=8.10$

$\mathrm{COD}=2,492 \mathrm{mg} / \mathrm{L}$

$\mathrm{BOD}=1,582 \mathrm{mg} / \mathrm{L}$

$\mathrm{TSS}=956 \mathrm{mg} / \mathrm{L}$

Abs-Org-X = $19.81 \mathrm{mg} / \mathrm{L}$

Lignin conc. $=452 \mathrm{mg} / \mathrm{L}$

The design components are mentioned below; 


\section{Design of Pumping Station}

Diameter of rising main $=12$ inches

Diameter of wet well $=15 \mathrm{ft}$

Diameter of suction pipe $=10$ inches

Power required $=2.5 \mathrm{hp}$

\section{Design of Approach Channel}

Rectangular channel; concrete lining

$\mathrm{WxD}=1.5 \mathrm{ft}$ x $1.0 \mathrm{ft}$

Bed slope $=1$ in 30

\section{Design of Screening Chamber}

Size of bars $=20 \times 20 \mathrm{~mm}$

Inclination $=450$

Bars spacing $=50 \mathrm{~mm}$

No. of bars $=6$

Frequency of cleaning $=7$ days

\section{Design of PST}

Rectangular tank; concrete

Depth $=12 \mathrm{ft}$ (including free board)

$\mathrm{LxW}=45 \mathrm{ft} \times 30 \mathrm{ft}$

Min BOD removal $=18 \%$

Min TSS removal $=35 \%$

\section{Design of UASB Reactor}

Diameter $=60 \mathrm{ft}$

Amount of biogas produced per day $=2,200 \mathrm{~m}^{3} /$ day

No. of person=3500 (@ o.6m³ $/$ capita $/$ day $)$

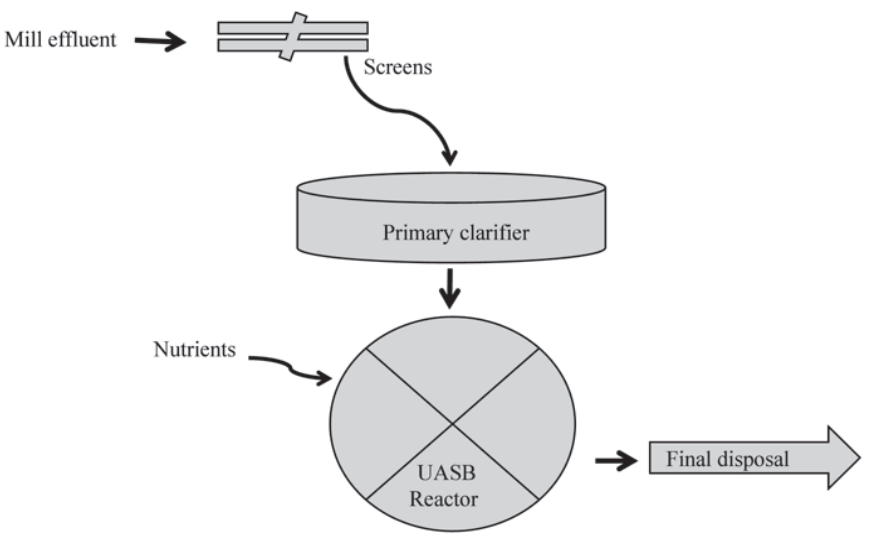

Figure 1. Layout of the Proposed Wastewater Treatment Plant of Paper Mill Effluent.

\section{Conclusion and Recommandations}

The following are the main conclusion derived from this study:

- The wastewater generated by the paper is highly polluted in terms of releasing a high strength effluent. The average COD, BOD, TSS and TDS concentration is $2,492 \mathrm{mg} / \mathrm{L}, 1,582 \mathrm{mg} / \mathrm{L}, 956 \mathrm{mg} / \mathrm{L}$ and 3,046 $\mathrm{mg} / \mathrm{L}$, respectively.

- The concentration of the AOX from the paper mill is more than $19 \mathrm{mg} / \mathrm{L}$.

- By designing a wastewater treatment plant based on a screening chamber, primary sedimentation tank and UASB reactor, the effluent pollution load could be decreased to a desirable level. This treatment plant can generate an estimated amount of $2,200 \mathrm{~m}^{3} /$ day of biogas that could be utilized for the domestic usage of more than 3,000 persons.

However, a comprehensive and long term study is suggested to determine the relation of COD and AOX formation during the paper manufacturing process, and to evaluate more cost-effective techniques for the pollution reduction caused by the paper mill effluent.

Arshad Ali is a professional Civil and Environmental Engineer. He has more than twelve years of professional experiences in various institutions and organizations of international repute. Presently, he is serving as an Assistant Professor at the National University of Sciences and Technology, Islamabad, Pakistan. There are more than 25 international research publications to his credit.

Corresponding address: aliarshado8@yahoo.com

Muhammad Jawed Iqbal is a professional Civil Engineer. He did his doctorate in civil engineering. He has been working on different environmental projects for the last fifteen years. He is the author of more than ten national and international research publications.

\section{References}

Arshad Ali, Hashim Nisar Hashmi, Inthikhab Ahmad Querashi, Athar Saeed, 2009, "Treatment feasibility of NSSC pulping effluent using UASB reactor" HYDRO Nepal, Journal of Water, Energy and Environment, vol 5, pp. 57-60.

Arshad Ali, Hashim Nisar Hashmi, 2010, "Treatment Feasibility of the Bleaching Effluent obtained from NSSC Pulp and Paper Mill in a UASB Reactor" Journal of Engineering and Applied Sciences, vol. 29, No. 3, pp. 43-31

AWWA and WEF, 2005, "Standard Methods for the examination of water and wastewater" (Washington DC: APHA Publication).

Bhatti, Z. I., K. Furukawa and M. Fujita, 1996, "Feasibility of methanolic wastes treatment in UASB rectors" Water Research, vol. 30, pp. 2559-2568.

Environmental Draft Report (Pak-EPA), 1999, "Environmental Technology Programme for Industries" (Islamabad: Federal Press).

Imran Hashmi, Shaukat Farooq and Sara Qaiser, 2009, Chlorination and water quality monitoring within a public drinking water supply in Rawalpindi Cantt (Westridge and Tench) area, Pakistan. Environ Monit Assess 158:393-403

Jehangir, M., 2002, Bacteriological Contamination and Upward Trend in Nitrate Contents, observed in Drinking Water of Rawalpindi and Islamabad. The 
Network Consumer Protection in Pakistan.

Khurrum, M., 2010, Performance evaluation of Sanjani and Simly Eater Treatment Plants. M.Sc Thesis, University of Engineering and Technology, Taxila, Pakistan.

Savant, D. V., R. Abdul-Rahman, D. R.Ranadi, 2005, "Anaerobic digestion of absorbable organic halides (AOX) from pulp and paper industry wastewater" Bioresource Technology, vol. 30, pp. 30-40.
Schellinkhout, A., 1993, "UASB technology for sewage treatment: experience with a full scale plant and its applicability in Egypt" Water Sci. Technol., vol. 27, No. 9, pp. 173-180.

Tallat, M.S., Hashim Nisar H., Arshad Ali, 2011, "Assessment of flashflood hazard in Pakistan". Proceedings of international conference on water resources engineering and management, UET Lahore, Pakistan.

\section{CALENDAR OF EVENTS - HYDROPOWER AND ELECTRICAL SYSTEMS}

20 August-6 September, 2012: Hydropower and the Environment sponsored by International Centre for Hydropower. Location: Trondheim, Norway. Contact Email: laura@ich.no. More info: www.ich.no

21-24 August, 2012: Regulation in Electricity Sector (Training Program, with specific reference to Renewable Energy (national level)), Location: Roorkee, India. Contact E-mail: ahec@iitr.ernet.in

26-31 August, 2012: International Council on large Electric Systems. Location: Paris, France. Contact Email: sylvie.bourneuf@cigre.org. More info: http://www.cigre.org

30 August-26 September, 2012: Rural Electrification for Developing Countries; sponsored by Hangzhou Regional Centre for Small Hydropower. Location: Hangzhou, China. Contact Email: hrc@hrcshp.org. More info: www. hrcshp.org

4-5 September, 2012: Hydropower Africa sponsored by Spintelligent. Location: Cape Town, South Africa. More info: www.hydropowerafrica. com

11-12 September, 2012: World Hydro Power Convention 2012: The Complete Hydro Power Convention in India. The Dual Theme for this Convention is 'Bilateral Cooperation' \& Partnering India's Growth with Speedier Development of Hydro Power Potential'. Location: New Delhi, India. Contact Email: info@fortunemediagroup. in. More info: www.fortunemediagroup.in

25-27 September, 2012: HydroVision Brazil sponsored by PennWell Corporation. Location: Rio de Janeiro, Brazil. Contact Email: lgasaway@ pennwell.com. More info: www.hydrovisionbrazil. com

25-27 September, 2012: DistribuTECH Brazil sponsored by PennWell Corporation. Location: Rio de Janeiro, Brazil. Contact Email: dboyne@ pennwell.com. Moreinfo: www.distributechbrasil. com

2-4 October, 2012: POWER-GEN Asia sponsored by PennWell Corporation. Location: Bangkok, Thailand. Contact Email: glenne@pennwell.com. More info: www.powergenasia.com

8-11 October, 2012: Transmission and Distribution
Smart Grids Europe. Location: Amsterdam, Netherlands. Contact Email: info@synergyevents.com. More info: http://www.td-europe.eu

8-12 October, 2012: Risk Management in Hydropower Development sponsored by International Centre for Hydropower. Location: Trondheim, Norway. Contact Email: laura@ich. no. More info: www.ich.no

15-17 October, 2012: International Electrotechnical Commission Technical Committee 4 Plenary Meeting. Location: Tokyo, Japan. Contact Email: iec_tc4@sympatico.ca. More info: www.iec.ch

18 October-28 November, 2012: Training on the Technology of Small Hydro for Francophone Countries in Africa sponsored by Hangzhou Regional Centre for Small Hydro Power. Location: Hangzhou, China. Contact Email: hrc@hrcshp. org. More info: www.hrcshp.org

29-31 October, 2012: Hydro 2012: International Conference and Exhibition, Innovative Approaches to Global Challenges. Location: Bilbao, Spain. More info: http://www.hydropower-dams.com/ hydro-2012.php?c_id=88

5-9 November, 2012: Concession AgreementsFrom Bidding through Negotiations to conclusion. Location: Pokhara, Nepal. More info: www.ich.no, www.ippan.org.np

6-8 November, 2012: POWER-GEN Africa sponsored by PennWell Corporation. Location: Johannesburg, South Africa. Contact Email: nigelb@pennwell.com. More info: www. powergenafrica.com

29-30 November, 2012: India Power Series Annual Conference: Generation, Transmission and Distribution. Location: New Delhi, India. More info: www.indiapower.org

11-13 December, 2012: POWER-GEN International sponsored by PennWell Corporation. Location: Orlando, Florida, USA. Contact Email: pgiconference@pennwell.com. More info: www. power-gen.com

4-6 February, 2013: POWER-GEN Middle East sponsored by PennWell Corporation. Location: Doha, Qatar. Contact Email: paperspgme@ pennwell.com. More info: www.power-genmiddleeast.com 